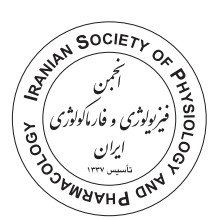

\title{
The blockade of $\mathrm{D}_{1} / \mathrm{D}_{2}$-like dopamine receptors in the lateral periaqueductal gray region affects mor- phine self-administration with and without exercise in rats
}

Somayeh Ahmadi ${ }^{1}$, Maryam Radahmadi ${ }^{2}$, Safoura Alizadeh ${ }^{1}$, Hojatallah Alaei $^{2 *}$ (DD, Mehdi Kargarfard ${ }^{2}$, Effat Ramshini ${ }^{3}$

1. Department of Physiology, Faculty of Physical Education and Sports Science, University of Isfahan, Isfahan, Iran

2. Department of Physiology, School of Medicine, Isfahan University of Medical Sciences, Isfahan, Iran

3. Department of Physiology, School of Medicine, Kerman University of Medical Sciences, Kerman, Iran

\begin{abstract}
Introduction: The periaqueductal gray (PAG) region plays an essential role in the modulation of nociception. Also, lateral PAG (IPAG) is involved in reward circuitry by the dopaminergic system in addiction. The present study investigated the blockade of $\mathrm{D}_{1} / \mathrm{D}_{2}$-like dopamine receptors in the lateral PAG region affects morphine self-administration with and without exercise.

Methods: Rats were divided into six groups. The rats were initially trained to receive small pellets of food by pressing an active lever in the self administration apparatus. Exercise groups were run on a treadmill at $20 \mathrm{~m} / \mathrm{min}, 5$ days/week, for 4 weeks before the surgery. Then rats were bilaterally implanted with cannulae in IPAG. The SCH23390 and sulpiride were microinjected into the $\mathrm{PAG}, 5 \mathrm{~min}$ before receiving morphine. Afterward, the animals were allowed to self administer morphine in $2 \mathrm{~h}$ sessions over 11 consecutive days. At last, the numbers of lever pressing, infusion times and withdrawal symptoms were measured.

Results: The results showed the number of active lever pressing was significantly increased in the morphine group compared to other groups in self-infusion during 11 days. Exercise significantly reversed the detrimental effects of morphine self-administration after five days. However, the synergistic effect of injected sulpiride into the IPAG region with exercise training was more pronounced on the amelioration of morphine than on the combinatory effect of SCH23390 with exercise.

Conclusion: The findings suggested that the $\mathrm{D}_{2}$ dopamine receptor in the IPAG region was involved in the morphine addiction via the dopaminergic system and exercise training in combination with antagonists could reduce the rewarding properties of morphine.
\end{abstract}

\author{
Keywords: \\ Periaqueductal gray \\ Self-administration \\ Exercise \\ Morphine
}

\footnotetext{
* Corresponding author: Hojatallah Alaei, alaei@med.mui.ac.ir

Received 25 August 2019; Revised from 4 October 2020; Accepted 18 October 2020

Citation: Ahmadi S, Radahmadi M, Alizadeh S, Alaei H, Kargarfard M, Ramshini E. The blockade of $\mathrm{D}_{1} / \mathrm{D}_{2}$-like dopamine receptors in the lateral periaqueductal gray region affects morphine self-administration with and without exercise in rats. Physiology and Pharmacology 2021; 25: 57-68. http://dx.doi.org/10.32598/ ppj.25.1.70
} 


\section{Introduction}

Several studies have localized the antinociceptive effects of morphine to periaqueductal gray (PAG) and other midbrain areas and have shown that interference with neural transmission within PAG alters the antinociceptive effects of systemically administered morphine (Meyer et al., 2009). In addition, morphine has been demonstrated to increase dopamine release in several brain areas, including the nucleus accumbens and prefrontal cortex and probably PAG. However, it is unknown whether morphine causes an increase in dopamine release within ventral PAG (Tobaldini et al., 2018). Although opioid-mediated mechanisms in ventral PAG have been explored extensively, much less is known about the role of other neurotransmitters. For example, a subpopulation of dopaminergic neurons within ventral PAG projects either locally or in forebrain regions is known to be involved in endogenous pain modulation ( $\mathrm{Li}$ et al., 2016). Dopamine $\mathrm{D}_{1}$-like and $\mathrm{D}_{2}$-like receptors are expressed within ventral PAG (Voulalas et al., 2017).

Indeed, dopamine is the central neurotransmitter in the morphine reward system of the brain (Hyman et al., 2006). Some studies conducted on the addiction process have elucidated the functionality of dopaminergic systems in animal experimental models such as selfadministration and conditioned place preference (Ahmadi et al., 2018; Hosseini et al., 2009b). They found that the family of dopamine receptors was directly involved in the reinforcement properties of drugs (reward behavior) (Lynch et al., 2013; Schetz and Sibley, 2007). Dopamine receptors are classified into two families based on their pharmacological features: the $\mathrm{D}_{1}$-like receptor including $\mathrm{D}_{1}$ and closely-related $\mathrm{D}_{5}$ receptors and the $\mathrm{D}_{2}$-like receptor consisting of $\mathrm{D}_{2}$ and closely-related $\mathrm{D}_{3}$ and $\mathrm{D}_{4}$ receptors (Avila-Luna et al., 2015). As presynaptic auto receptors, $D_{2}$-like dopamine receptors $\left(\mathrm{D}_{2} \mathrm{Rs}\right)$ inhibit the dopamine release (AvilaLuna et al., 2015). Accordingly, it is possible that the $\mathrm{D}_{2}$ receptor contributes to the induction of pleasure and stimulates the desire of drug consumption in drug abusers (Silva and Heyman, 2001).

Preclinical studies report that physical activity, especially aerobic exercise (in running wheel, treadmill and swimming) decreased the self-administration of morphine, nicotine, cocaine, methamphetamine and heroine (Ahmadi et al., 2018; Charmchi et al., 2016).
Moreover, aerobic activity produces some alteration in central dopamine and opioid systems (Charmchi et al., 2016; Liu et al., 2019). Furthermore, most researches have demonstrated the effect of exercise on selfadministration of drugs in different areas of the brain (Charmchi et al., 2016). Nevertheless, few studies have examined the effects of $\mathrm{D}_{1}$ and $\mathrm{D}_{2}$ antagonists on the latera PAG (IPAG) region with and without exercise on morphine addiction. Hence, exercise could be used as a valuable approach to help individuals to recover from addiction (Smith and Lynch, 2011). Therefore, the present study was designed to clarify the blockade of $D_{1}$ - and $\mathrm{D}_{2}$-like receptors modifying morphine addiction (self-administration) via involvement of the IPAG region with and without exercise in rats.

\section{Material and methods}

\section{Animals and experimental design}

Eighty male Wistar rats obtained from Pasteur Institute, Tehran, Iran, with an initial body weight of $250-300 \mathrm{~g}$. The rats were housed under standard laboratory conditions with $12 \mathrm{~h}$ light/dark cycle (07:00 - 19:00) under controlled temperature $\left(22 \pm 2^{\circ} \mathrm{C}\right)$ and humidity $(50 \pm 5 \%)$ with available food and water $a d$ libitum. The rats were allowed to adapt themselves to the laboratory condition for at least 1 week before surgery. The Ethics Committee of Animal Use at Isfahan University of Medical Sciences approved the study (IR. MUI.MED.REC. 193083) and all experiments were conducted in compliance with the National Institute of Health Guide for the Care and Use of Laboratory Animals (NIH Publications No. 80-23, revised 2011). In total, eighty rats were used for these experiment that twenty rats were excluded due to misplaced cannulas and sixty reminding rats were randomly selected and divided into six groups $(\mathrm{n}=10)$ :

1- Morphine (M) group: rats received morphine $(5 \mathrm{mg} / \mathrm{ml})$ in saline solution during self-administration sessions; 2- $\mathrm{D}_{1}$ antagonist + morphine $\left(\mathrm{D}_{1}+\mathrm{M}\right)$ group: rats received $D_{1}$ antagonist $(4 \mu \mathrm{g} / 0.5 \mu 1$ in DMSO solution within $1 \mathrm{PAG}$ ), $5 \mathrm{~min}$ before receiving morphine during self-administration sessions; $3-\mathrm{D}_{2}$ antagonist + morphine $\left(\mathrm{D}_{2}+\mathrm{M}\right)$ group: rats received $\mathrm{D}_{2}$ antagonist $(4 \mu \mathrm{g} / 0.5 \mu 1$ in saline solution within $1 \mathrm{PAG}), 5 \mathrm{~min}$ before receiving morphine during self-administration sessions; 4- exercise + morphine $(\mathrm{Ex}+\mathrm{M})$ group: the rats run on the treadmill for 4 weeks and upon a 30min break, they 
received morphine during self-administration sessions; 5- exercise $+\mathrm{D}_{1}$ antagonist + morphine $\left(\mathrm{Ex}+\mathrm{D}_{1}+\mathrm{M}\right)$ group: rats run on the treadmill for 4 weeks and upon a 30 min break, they received $\mathrm{D}_{1}$ antagonist and morphine during self-administration sessions; 6- exercise $+\mathrm{D}_{2}$ antagonist + Morphine $\left(\mathrm{Ex}+\mathrm{D}_{2}+\mathrm{M}\right)$ group: rats run on the treadmill for 4 weeks and upon a 30min break, they received $\mathrm{D}_{2}$ antagonist and morphine during selfadministration sessions.

All animals at the end of experiment (11 days after morphine administration) received naloxone $(2 \mathrm{mg} / \mathrm{kg}$, SC) and withdrawal signs were recorded for $30 \mathrm{~min}$ (Figure 1).

\section{Drugs}

In the present study, the following drugs were used: morphine sulfate (Temad, Tehran Iran) and SCH23,390 (Tocris Bioscience, Bristol, UK), a $\mathrm{D}_{1}$ receptor antagonist, which were dissolved in sterile saline (0.9\%). Sulpiride (Tocris Bioscience, Bristol, UK), a $\mathrm{D}_{2}$ receptor antagonist, was dissolved in $10 \%$ DMSO (Sigma-Aldrich, Germany). Naloxone hydrochloride (Sigma Co., USA) was dissolved in saline $0.9 \%$.

\section{Treadmill running}

The rats were familiarized with the treadmill running 7 days before the experiments how to run on the treadmill. This also helped use to identify sick or lazy rats, which would be excluded from the experiment (20 male rats). The remaining rats (60 rats) underwent the intravenous cannulation and allowed to recover from the surgery for 7 days. The running period for all the groups consisted of 5-60min of running, five days per week, for 4 weeks on a flat treadmill at a rate of 5-20m/min. After surgery and 7 days of recovery, due to maintaining aerobic capacity the rats run on the treadmill for $15 \mathrm{~min}$ at a rate of $15 \mathrm{~m} / \mathrm{min}$. After a $30 \mathrm{~min}$ break, they were placed in the selfadministration apparatus and continuous experiments were conducted for 11 days (Ahmadi et al., 2018). Indeed, the non-runners groups were put on the treadmill without running for the same duration as runners (Hoveida et al., 2011).

Surgery (stereotaxic and jugular vein catheterization)

The rats were anesthetized by intraperitoneal injection of ketamine $(100 \mathrm{mg} / \mathrm{kg})$ and xylazine $(10 \mathrm{mg} / \mathrm{kg})$ (Haghparast et al., 2013). The animals were placed into the stereotaxic device (Stoelting Co., USA). The scalp was retracted and the area of surrounding bergma was cleaned and dried. In addition, lidocaine with epinephrine $(0.2 \mathrm{ml})$ was injected in several locations around the incision (Haghparast et al., 2013). One stainless-steel guide cannula (23-gauge, $12 \mathrm{~mm}$ ) was unilaterally implanted $1 \mathrm{~mm}$ above the intended site of injection (IPAG) according to the rat brain atlas (Paxinos and Watson, 2006). The coordinates for IPAG were determined by the rat brain atlas, anterior/posterior= $-7.56 \mathrm{~mm}$ caudal to bergma, medial $/$ lateral $=+1 \mathrm{~mm}$ and dorsal $/$ ventral $=-5.4 \mathrm{~mm}$ ventral from the skull surface. The guide cannula was secured in place using two stainless steel screws anchored to the skull. Then, cannula was inserted into the jugular vein.

The cannula was guided subcutaneously up to the skull and connected to polyethylene tubing where it was fixed to a metal tube and secured to the skull with small screws, fixed with dental acrylic cement. After the cement was completely dried and hardened, two stainless steel stylets were used to occlude the guide cannula during the recovery period. Penicillin-G 200,000 IU/ml (0.2$0.3 \mathrm{ml} / \mathrm{rat}$, single dose, intramuscular) was administered immediately after surgery. After surgery, the animals were placed in individual home cages and they were allowed to recover from the operation for 7 days before performing experiments (Sadeghzadeh et al., 2015).

\section{Drug administration}

Microinjections were performed by lowering a stainless steel injector cannula (30-gauge needle) with a length of $1 \mathrm{~mm}$ longer than the guide cannula into CA1. The injector cannula was connected to a $1-\mu 1$ Hamilton syringe by polyethylene tubing (PE-20), then

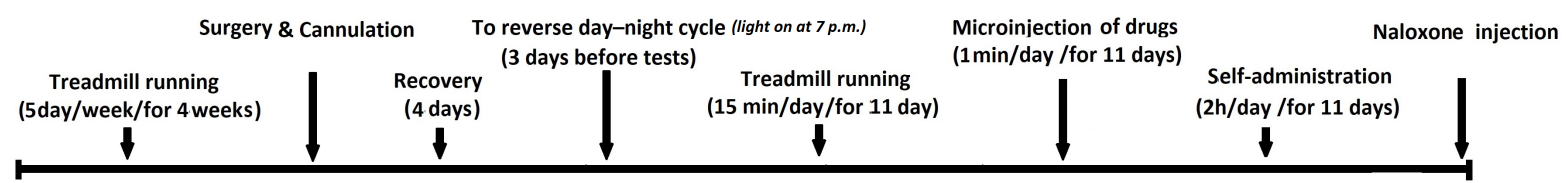

FIGURE 1. Experimental design for all groups. 
drug solution or vehicle bilaterally was infused in a total volume of $0.5 \mu 1 /$ rat over $60 \mathrm{~s}$ and was left for the $60 \mathrm{~s}$ extra time and followed by replacement of the obturator (Sadeghzadeh et al., 2015).

\section{Self-administration apparatus}

The rats were initially trained to press a lever using food as reinforcement to acquire drug selfadministration before being surgically implanted with a chronic intravenous jugular catheter. Training and testing were carried out in standard operant conditioning cages $(21 \times 21 \times 28 \mathrm{~cm})$ placed in a sound-attenuated room, ventilated with fans, based on the bothers of the previously-used method (Alaei et al., 2005; Sahraei et al., 2004) with minor modifications. The apparatus was equipped with active and passive levers, $2 \mathrm{~cm}$ above the floor, with a red light located $4 \mathrm{~cm}$ above the active lever. The intravenous cannula was connected to an infusion pump via a swivel, allowing the animal to move relatively freely (Hosseini et al., 2009a). Pressing of the active lever, marked by a light, resulted in a 10 s infusion of $0.1 \mathrm{ml}$ fluid through an infusion pump. The fluid was saline in the morphine group $(5 \mathrm{mg} / \mathrm{ml})$ in the other groups. Depression of the active lever during this time (10s) did not affect the infusion of the drug. Pressing of the passive lever had no programmed consequences. In this study, the number of lever pressing was regarded as a measure of the reinforcing action of the drug (Moradi et al., 2015; Reisi et al., 2014).

\section{Training phase}

Ten days before the experiments, the animals were transferred to a special room and the day-night cycle 12/12 hours were reversed into night-day cycle 12/12 hours (light on at $7 \mathrm{pm}$ ). The experiments were subsequently performed during the dark phase. Before the surgery, the training program was started after $24 \mathrm{~h}$ of food restriction. The animals were placed in the selfadministration apparatus where a lever filled with food pellets was available. Each lever pressing resulted in the delivery of a 100mg pellet (Moradi et al., 2015). Each rat was allowed to have self-training until 40 pellets were received. Following acquisition of the lever pressing behavior, the rats were returned to ad libitum food and allowed to gain their weight for 3 days, before the surgery was performed (Hosseini et al., 2009a; Reisi et al., 2014).

\section{Procedure}

Seven days after recovery and following $24 \mathrm{~h}$ of food restriction, the rats were placed in the operant chambers where a lever filled with food pellets was available. Each active lever pressing resulted in the delivery of a $100 \mathrm{mg}$ pellet. The jugular cannula of rats was connected to an infusion pump and the animals were placed in the self-administration apparatus for $2 \mathrm{~h}$ each day on an FR-1 schedule (Hosseini et al., 2009a). The trained animals were allowed to press active and passive levers freely. By pressing the active lever, the rats received $0.1 \mathrm{ml}$ of morphine and small pellets in the first 6 days and morphine without pellets in the final 5 days of the experiment. Pressing the passive lever did not deliver fluid or food. In the first 6 days of self-administration period, the availability of food was restricted to reduce body weight by $15 \%$, which has been shown to facilitate the initiation of intravenous self-administration (McDougall et al., 2005). Changes of less than $15 \%$ in the number of injections in the last 3 days were regarded as baseline. In the next 5 days, the animals had free access to their ad libitum food. The catheters were flushed daily with $0.1 \mathrm{ml}$ saline containing heparin sulfate $(50 \mathrm{U} / \mathrm{ml})$ during the recovery period as well as before and after self-administration sessions. All operant sessions were conducted during the animals' dark cycle. Catheter potency was tested by the injection of $0.1 \mathrm{ml}$ of sodium pentobarbital solution $(10 \mathrm{mg} / \mathrm{ml})$ into the catheter and observation of animal behavior. Animals with patent catheters exhibit prominent signs of anesthesia (loss of muscle tone) a few seconds after the administration (Hosseini et al., 2009a).

\section{Withdrawal syndrome signs}

The withdrawal syndrome was precipitated with an intraperitoneal injection of $2.0 \mathrm{mg} / \mathrm{kg}$ naloxone HCL, dissolved in saline. Withdrawal signs (climbing, jumping, grooming, defecation, teeth chattering, stretch, genital grooming and shaking) were recorded within $30 \mathrm{~min}$ after the injection of naloxone at the last day of the experiment.

\section{Histological verification}

Immediately after the last session, all rats were anesthetized with a high dose of ether and perfused transcardiacally with a phosphate-buffered saline solution $(\mathrm{pH}=7.4)$ (Hasue and Shammah-Lagnado, 
2002). The brains were removed and placed in formaldehyde (4\%). The brains were removed and kept in a $4 \%$ fresh formalin solution for 3 days and sliced coronal in $50 \mu \mathrm{m}$ sections through cannula placement sections. The neuroanatomical locations of cannula tips were confirmed using the rat brain atlas. The data reported here are only from animals whose placements of cannula tips were histologically verified (Figure 2).

\section{Statistical analysis}

Data have been presented as mean $\pm \mathrm{SEM}$. The number of active and passive levers pressings of final 5 days was compared between different groups. The number of passive lever pressing between different groups (summed over ten sessions) was compared using oneway analysis of variance (ANOVA) and Turkey's post hoc test. In addition, the ANOVA test was used to analyze withdrawal signs. Then number of active and passive lever pressings every session and the number of self-infusion between different groups were compared to each other using repeated-measures one-way analysis of variance (ANOVA) and Turkeys' post hoc test. The criterion for statistical significance was $P<0.05$.

\section{Results}

\section{Initiation of drug self-administration}

The number of active levers pressing was significantly lower in $\left(\mathrm{D}_{1}+\mathrm{M}\right.$ and $\left.\mathrm{D}_{2}+\mathrm{M}\right)$ groups than in the morphine (M) group, showing that $\mathrm{D}_{1}$ and $\mathrm{D}_{2}$ antagonists reduced morphine self-administration $(P<0.05$ to $P<0.001$ on all the experimental days; Figure 3). No significant $(P>0.05)$ difference was found between $\mathrm{D}_{1}+\mathrm{M}$ and $\mathrm{D}_{2}+\mathrm{M}$ groups in the number of reinforcement lever pressing (Figure 3).

No significant reduction was found in the number of self-infusion (SI) between $\mathrm{D}_{1}+\mathrm{M}$ and $\mathrm{D}_{2}+\mathrm{M}$ groups. The number of self-infusion was significantly lower in $\mathrm{D}_{1}+\mathrm{M}$ and $\mathrm{D}_{2}+\mathrm{M}$ groups than in the $\mathrm{M}$ group during all days ( $P<0.05$ and $P<0.001$; respectively), indicating that $\mathrm{D}_{1}$ and $\mathrm{D}_{2}$ antagonists could decrease the consumption of morphine (Figure 4).

Figure 5 presents the numbers of reinforcement lever pressing in the final 5 days. This number of levers pressing were significantly $(P<0.001)$ lower in the $\mathrm{Ex}+\mathrm{M}$ group than in the $\mathrm{M}$ group, demonstrating that exercise could reduce morphine self-administration. The number of active lever pressing was significantly decreased in $\mathrm{Ex}+\mathrm{D}_{1}+\mathrm{M}$ and $\mathrm{Ex}+\mathrm{D}_{2}+\mathrm{M}$ groups than in the $\mathrm{Ex}+\mathrm{M}$ group $(P<0.001$ in both of them; Figure 5).

As Figure 5 shows, a significant $(P<0.05)$ difference was found in the number of reinforcement lever pressing in the $\mathrm{Ex}+\mathrm{D}_{1}+\mathrm{M}$ group than in the $\mathrm{Ex}+\mathrm{D}_{2}+\mathrm{M}$ group, revealing that $\mathrm{D}_{2}$ antagonist associated with exercise was more effective than $\mathrm{D}_{1}$ antagonist associated with exercise in the reduction of morphine self-administration. The number of reinforcement lever pressing was significantly reduced in both $\mathrm{Ex}+\mathrm{D}_{1}+\mathrm{M}$ and $\mathrm{Ex}+\mathrm{D}_{2}+\mathrm{M}$ groups compared to the $\mathrm{M}$ group $(P<0.05$ and $P<0.001$; respectively).

Figure 6 presents the number of self-infusions in the

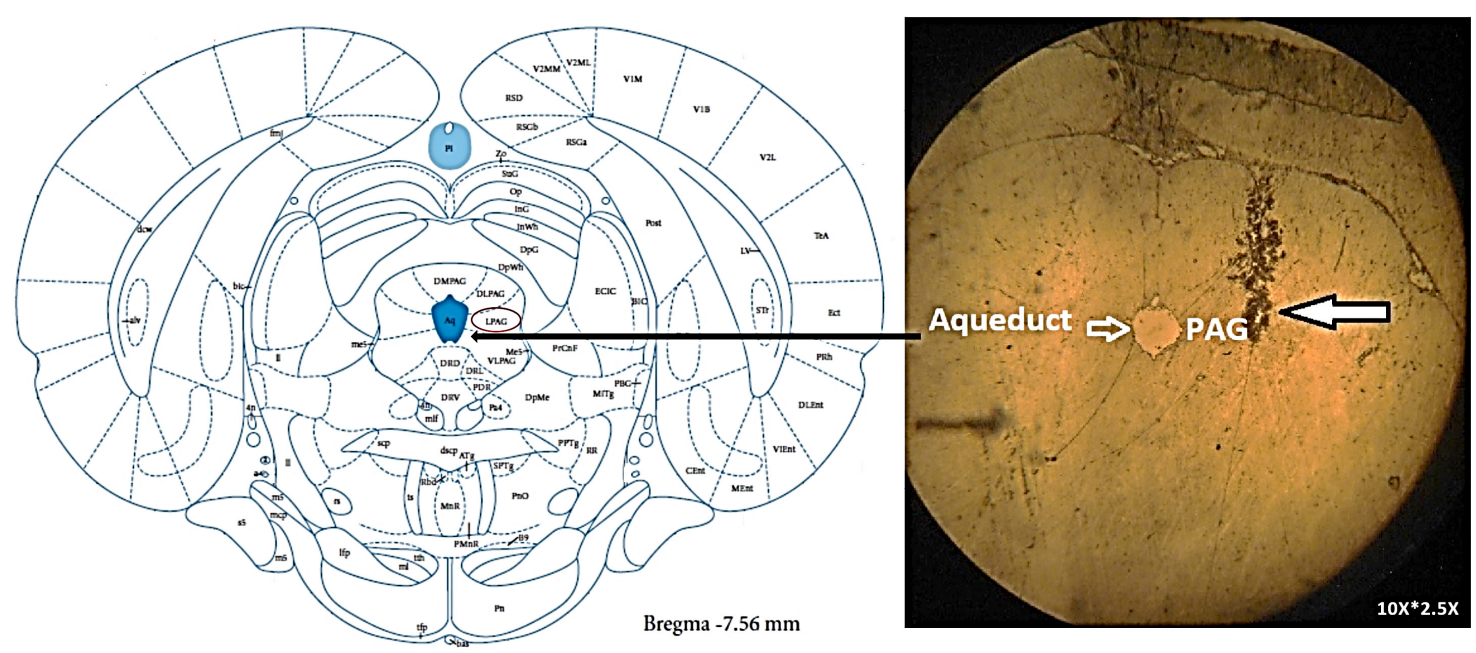

FIGURE 2. The position of the injection cannula tips in the lateral periaqueductal gray (LPAG) regions for all rats included in the statistical analysis. All histological section of brain were $50 \mu \mathrm{m}(10 \mathrm{x} * 2.5 \mathrm{x})$. 


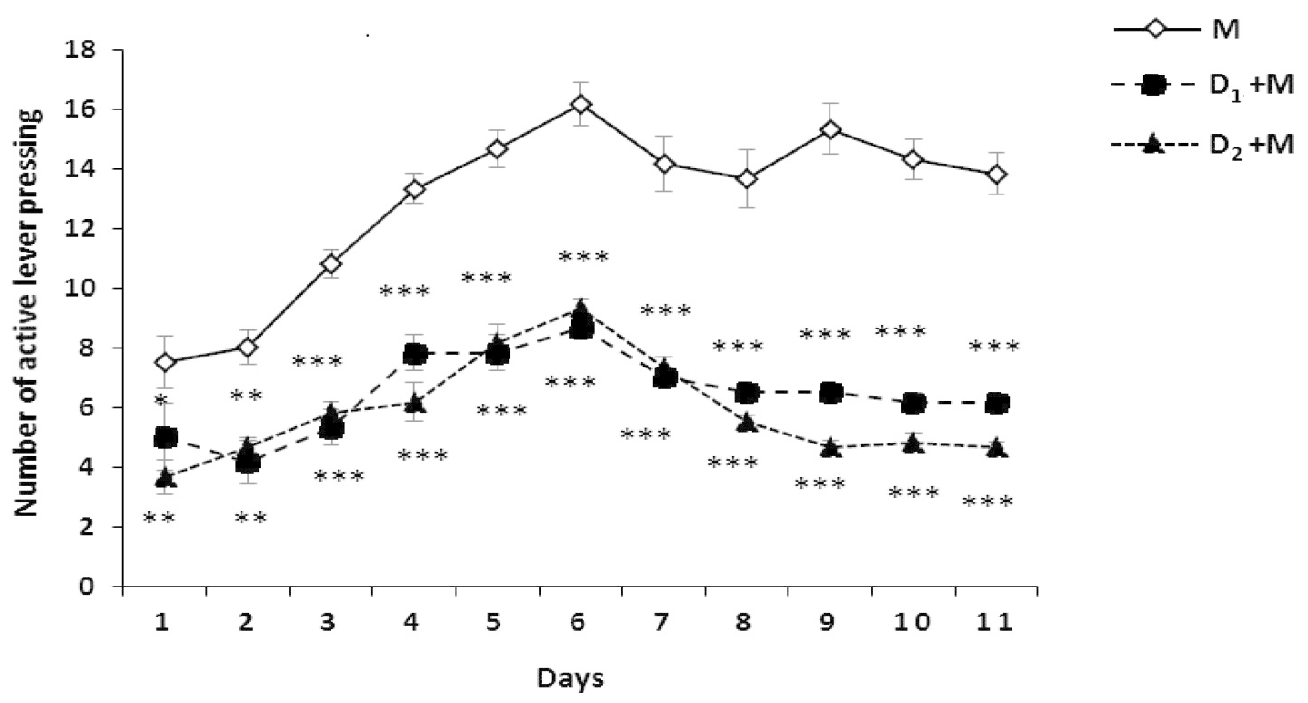

FIGURE 3. Comparison of the number of reinforcement lever pressing between three groups during 11 days $\left(M, D_{1}+M\right.$ and $\left.D_{2}+M\right)$. The numbers of the RL were compared in different groups using the repeated measure the one-way ANOVA followed by Tukey's post hoc test. Values are expressed as the mean \pm SEM. No significant difference was observed between $\mathrm{D}_{1}+\mathrm{M}$ and $\mathrm{D}_{2}+\mathrm{M}$ groups.

M: Morphine group; $\mathrm{D}_{1}+\mathrm{M}: \mathrm{D}_{1}$ antagonist + Morphine group; $\mathrm{D}_{2}+\mathrm{M}: \mathrm{D}_{2}$ antagonist + Morphine group; ${ }^{*} P \leq 0.05,{ }^{* *} P \leq 0.01,{ }^{* * *} P \leq 0.001$ compared to the M group.

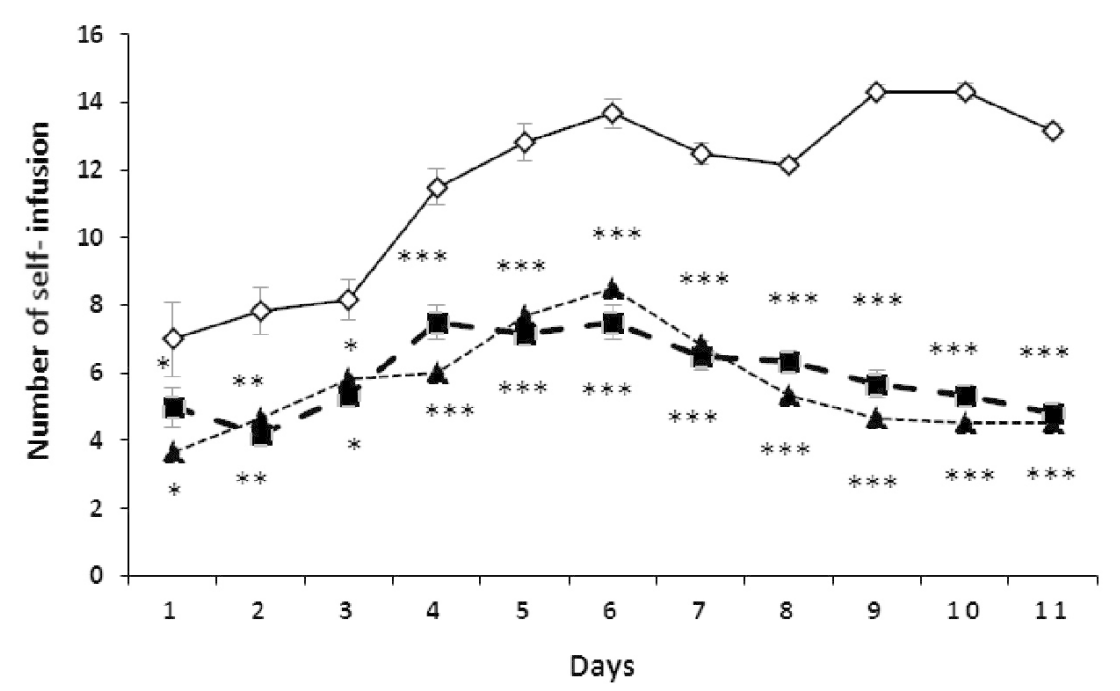

FIGURE 4. Comparison of self-infusion between three groups during 11 days (Morphine, $\mathrm{D}_{1}+\mathrm{M}$ and $\mathrm{D}_{2}+\mathrm{M}$ ). The numbers of self- infusion were compared in different groups using the repeated measure the one-way ANOVA followed by Tukey's post hoc test. Values are expressed as the mean \pm SEM. No significant difference in the number of self-infusion was observed between $\mathrm{D}_{1}+\mathrm{M}$ and $\mathrm{D}_{2}+\mathrm{M}$ groups.

M: Morphine group; $\mathrm{D}_{1}+\mathrm{M}: \mathrm{D}_{1}$ antagonist + Morphine group; $\mathrm{D}_{2}+\mathrm{M}: \mathrm{D}_{2}$ antagonist + Morphine group. ${ }^{*} P \leq 0.05,{ }^{* *} P \leq 0.01,{ }^{* * * *} P \leq 0.001$ compared to the M group.

last 5 days of morphine self-administration. Running activity significantly $(\mathrm{P}<0.001)$ decreased the number of self-infusions during the past 5 days in the $\mathrm{M}+\mathrm{E}$ group than in the $\mathrm{M}$ group, so that the running activity reduced self-administration of morphine. The number of self-infusion was significantly $(P<0.001)$ decreased in $\mathrm{Ex}+\mathrm{D}_{1}+\mathrm{M}$ and $\mathrm{Ex}+\mathrm{D}_{2}+\mathrm{M}$ groups than in the $\mathrm{Ex}+\mathrm{M}$ group (Figure 6). The number of self-infusion was significantly $(P<0.05)$ lower in the $\mathrm{Ex}+\mathrm{D}_{2}+\mathrm{M}$ group than in the $\mathrm{Ex}+\mathrm{D}_{1}+\mathrm{M}$ group, showing that $\mathrm{D}_{2}$ antagonist associated with exercise was more effective than $D_{1}$ antagonist associated with exercise in the presentation of morphine self-administration. The number of selfinfusion in the final 5 days was significantly $(P<0.001)$ lower in both $\mathrm{Ex}+\mathrm{D}_{1}+\mathrm{M}$ and $\mathrm{Ex}+\mathrm{D}_{2}+\mathrm{M}$ groups than in the $\mathrm{M}$ group (Figure 6). No significant $(P>0.05)$ difference was found in the number of passive lever pressing between all groups during 11 days (Figure 7). 


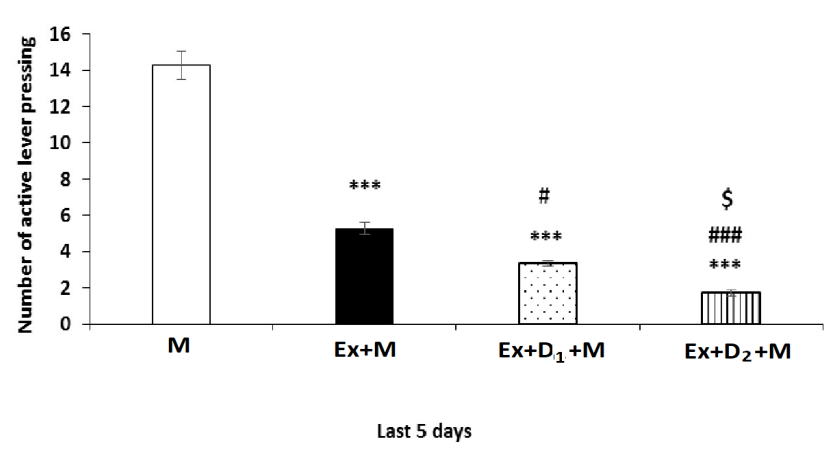

FIGURE 5. Comparison of active lever pressing between the four groups in the last 5 days $\left(\mathrm{M}, \mathrm{Ex}+\mathrm{M}, \mathrm{Ex}+\mathrm{D}_{1}+\mathrm{M}\right.$ and $\left.\mathrm{Ex}+\mathrm{D}_{2}+\mathrm{M}\right)$. Statistical analysis was performed using the one-way ANOVA followed by Tukey's post hoc test. Values are expressed as the mean \pm SEM.

M: Morphine group; Ex+M: Exercise+ Morphine group; Ex$+\mathrm{D}_{1}+\mathrm{M}$ : Exercise $+\mathrm{D}_{1}$ antagonist + Morphine group; $\mathrm{Ex}+\mathrm{D}_{2}+\mathrm{M}$ : Exercise $+\mathrm{D}_{2}$ antagonist + Morphine group.

${ }^{* * *} P \leq 0.001$ compared to the M group; ${ }^{\#} P \leq 0.05,{ }^{\# \# \#} P \leq 0.001$ compared to the $\mathrm{Ex}+\mathrm{M}$ group; ${ }^{\$} P \leq 0.05$ compared to the $\mathrm{Ex}+\mathrm{D}_{1}+\mathrm{M}$ group.

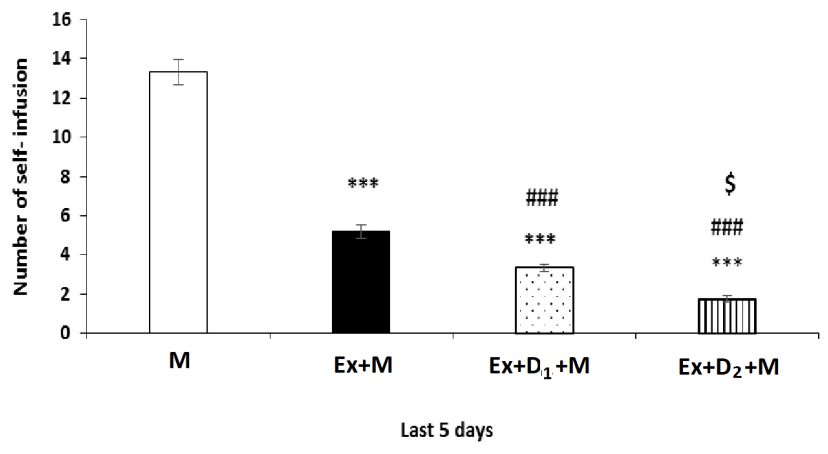

FIGURE 6. Comparison of the number of self-infusion between the four groups in the last 5 days $\left(\mathrm{M}, \mathrm{Ex}+\mathrm{M}, \mathrm{Ex}+\mathrm{D}_{1}+\mathrm{M}\right.$ and $\mathrm{Ex}-$ $\left.+\mathrm{D}_{2}+\mathrm{M}\right)$. Statistical analysis was conducted using the one-way ANOVA followed by Tukey' post hoc test. Values are expressed as the mean \pm SEM.

M: Morphine group; Ex+M: Exercise + Morphine group; Ex$+\mathrm{D}_{1}+\mathrm{M}$ : Exercise $+\mathrm{D}_{1}$ antagonist + Morphine group; $\mathrm{Ex}+\mathrm{D}_{2}+\mathrm{M}$ : Exercise $+\mathrm{D}_{2}$ antagonist + Morphine group.

${ }^{* * * *} P \leq 0.001$ compared to the M group; ${ }^{*} P \leq 0.05,{ }^{\# \# P} P \leq 0.001$ compared to the $\mathrm{Ex}+\mathrm{M}$ group; ${ }^{\mathrm{P}} \mathrm{P} \leq 0.05$ compared to the $\mathrm{Ex}+\mathrm{D}_{1}+\mathrm{M}$ group.

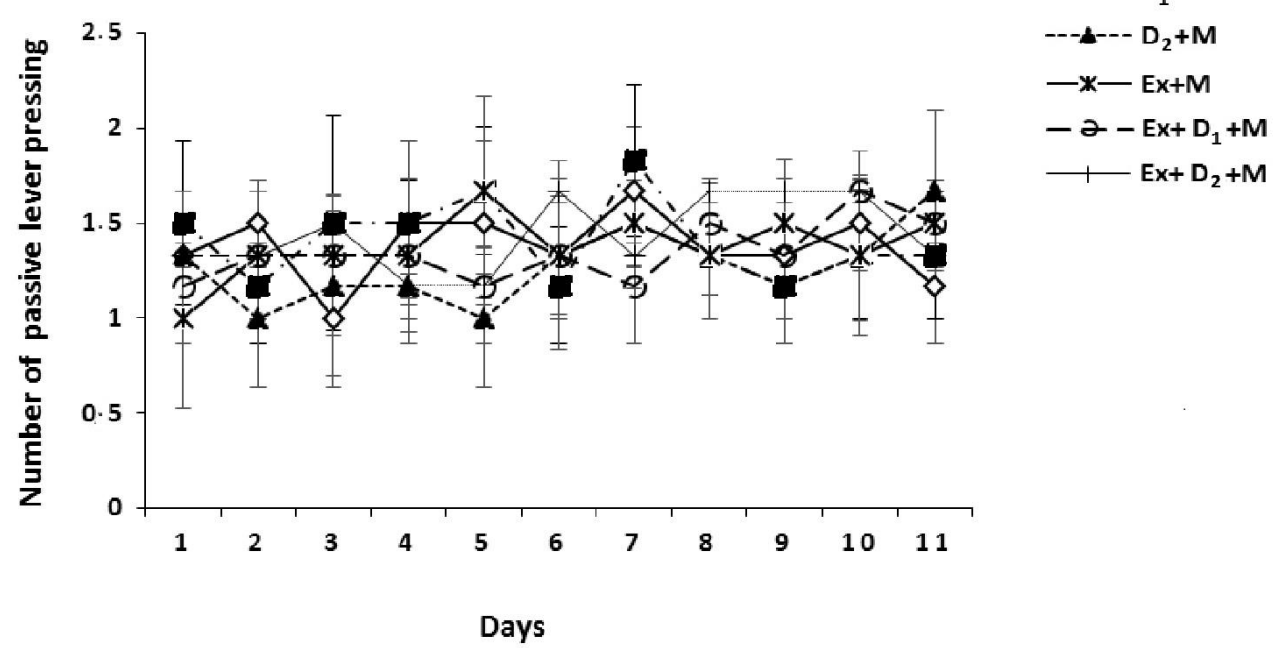

FIGURE 7. Comparison of passive lever pressing between all groups of animals during 11 days $\left(\mathrm{M}, \mathrm{Ex}+\mathrm{M}, \mathrm{Ex}+\mathrm{D}_{1}+\mathrm{M}\right.$ and $\left.\mathrm{Ex}+\mathrm{D}_{2}+\mathrm{M}\right)$. The numbers of passive lever were compared in different groups using the repeated measure the one- way ANOVA followed by Tukey's post hoc test. Values are expressed as the mean \pm SEM. No significant difference in the number of passive lever pressing was observed between the groups.

M: Morphine group; $\mathrm{D}_{1}+\mathrm{M}$ : $\mathrm{D}_{1}$ antagonist + Morphine group; $\mathrm{D}_{2}+\mathrm{M}: \mathrm{D}_{2}$ antagonist + Morphine group; Ex $+\mathrm{M}$ : Exercise + Morphine group; $\mathrm{Ex}+\mathrm{D}_{1}+\mathrm{M}$ : Exercise $+\mathrm{D}_{1}$ antagonist + Morphine group; Ex $+\mathrm{D}_{2}+\mathrm{M}$ : Exercise $+\mathrm{D}_{2}$ antagonist + Morphine group.

\section{Withdrawal syndrome signs}

Table 1 shows the effects of exercise associated with drugs (morphine, $\mathrm{D}_{1}$ and $\mathrm{D}_{2}$ antagonists) on withdrawal syndrome signs. All of the withdrawal signs (except jumping) were significantly $(P<0.001)$ attenuated in the $\mathrm{M}+\mathrm{Ex}$ group than in the $\mathrm{M}$ group. The withdrawal syndrome signs (climbing, grooming, stretch and genital grooming) were significantly lower in the $\mathrm{D}_{2}+\mathrm{M}+\mathrm{Ex}$ group than in the $\mathrm{D}_{1}+\mathrm{M}$ group $(P<0.05$ to $P<0.001)$. Most of the withdrawal signs, especially genital grooming, jumping and shaking significantly $(P<0.05$ to $P<0.001)$ were decreased in the $\mathrm{D}_{2}+\mathrm{M}+\mathrm{Ex}$ group than in the $\mathrm{D}_{2}+\mathrm{M}$ group.

\section{Discussion}

This study showed that the injection blockade of $\mathrm{D}_{1}$ and $\mathrm{D}_{2}$-like receptors within the lateral periaqueductal gray region reduced morphine self-administration with and without exercise in rats. According to our results, $\mathrm{D}_{1}$ and $\mathrm{D}_{2}$ antagonists reduced morphine active lever 


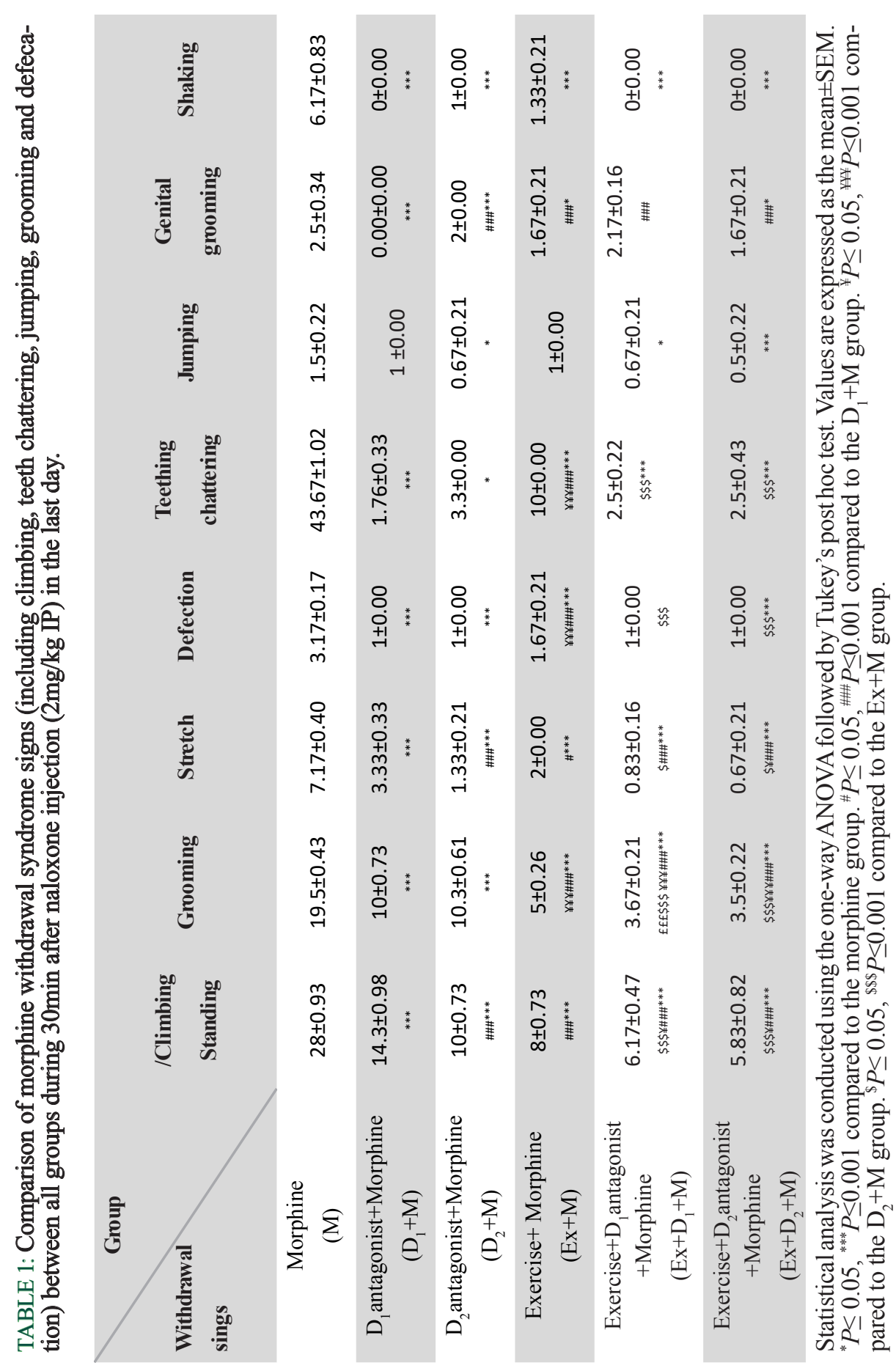

pressing compared to the morphine group, and the number of self-infusion was significantly decreased in $\mathrm{D}_{1}$ and $\mathrm{D}_{2}$, suggesting the attenuation reinforcement effects of morphine. Furthermore, no significant difference in the number of passive lever pressing between the morphine group and the other groups, proving that the animal behavior was directed to obtain the reward effects of morphine. In agreement with these results, it was demonstrated that morphine induced euphoria through $\mu$ opioid receptors activation and increased dopamine transmission during sensitization development (Meyer et al., 2009; Smith and Lynch, 2011). In animal studies, some neuro-adaptive changes were also observed in dopamine $\mathrm{D}_{1}$ and $\mathrm{D}_{2}$ receptors during sensitization (Łupina et al., 2018).

Previous findings also revealed that analgesia induced by morphine was mediated by $\mathrm{D}_{1}$ and $\mathrm{D}_{2}$-like dopamine receptors (Nestler, 2001; Tobaldini et al., 2018). The 
present results and other researchers suggested that $\mathrm{D}_{1}$ and $\mathrm{D}_{2}$ dopamine receptors were involved in morphineinduced analgesia and inhibited behavioral sensitization to morphine through the release of dopamine from dopaminergic neuron by stimulation of these receptors in nucleus accumbens (Charmchi et al., 2016) and blockade of these receptors in IPAG.

According to these connections and the key role of dopamine in drug reward, IPAG could participate in opiate reward. Microinjection of dopamine antagonists into IPAG reduced the reinforcement effects of morphine. Consistent with these findings, other studies reported that PAG dopamine network was involved in the rewarding and sensitizing properties of heroin (Lane et al., 2005), suggesting that repeated opiate drug exposure induces biochemical changes in specific brain regions to mediate the reinforcing actions of drugs, mostly the mesolimbic dopamine system (Flores et al., 2004). Previous studies revealed that the direct injection of dopamine antagonists into the PAG attenuated the ant nociceptive effects of morphine and heroin (Meyer et al., 2007). This dopaminergic modulation of nociception within ventral PAG is likely involved in the development of opioid tolerance and drug seeking. Ventral PAG was known to play an important role in tolerance to opioids (Boecker et al., 2008; Meyer et al., 2009). In addition, the development of opioid mediated reinforcement and sensitization has been shown to be dependent on ventral PAG dopamine (Meyer et al., 2007). In the current study, the microinjection of dopamine receptors antagonists into $\mathrm{PAG}$ also reduced the properties of morphine. Overall, these experiments indicated an interaction between morphine and dopamine within IPAG. The previous research also found that anti-nociception of dopamine was induced by activation of $\mathrm{D}_{2}$ receptors not by $\mathrm{D}_{1}$ (Liu et al., 2016), while the present study could not find significant differences between $\mathrm{D}_{1}$ or $\mathrm{D}_{2}$ antagonists in morphine addiction. Others reported that many of the behavioral alterations after using morphine were associated with the activity of $\mathrm{D}_{2}$-expressing in the brain (Lane et al., 2005; Yoshida et al., 2019).

Previous studies indicated that exercise induced euphoria, especially endurance exercise significantly increased the level of euphoria (Greenwood and Fleshner, 2011). The release of endogenous opioids also occurred in front-limbic brain regions after sustained physical exercise and changes of the central opioid receptor binding were identified in prefrontal regions after $2 \mathrm{~h}$ of long-distance running (Greenwood and Fleshner, 2011). Furthermore, treadmill running increased the effect of $\mathrm{D}_{2}$ antagonist within IPAG to prevent effects of dopamine on morphine-induced sensitization. Others showed that neurotransmitters and endogenous opioids were evoked in the brain by exercise (Robison et al., 2018), similar to those induced by substances of abuse. For example, the levels of beta-endorphins, dopamine and norepinephrine were increased by exercise and drugs, and abuse of drugs was reduced by combination of exercise and morphine (Smith et al., 2018). Others also reported that disturbances of the brain dopaminergic activity (including low striatal $\mathrm{D}_{2}$ receptor levels) induced compulsive behaviors in substance abuse (Lane et al., 2005; Nestler, 2001). Similarly, treadmill running significantly reduced morphine sensitization through $\mathrm{D}_{2}$ receptors within IPAG. The evidence shows that exercise induces higher level of $\mathrm{D}_{2} \mathrm{R}$ binding in striatum and plays a crucial role in addiction (Volkow and Baler, 2014). In our results, no significant differences were found in $\mathrm{D}_{1}$ and $\mathrm{D}_{2}$ dopamine receptors antagonists after injection within IPAG to reduce reinforcement effects of morphine in rats, but aerobic exercise, along with injection of $\mathrm{D}_{2}$ antagonist increased this reduction into IPAG. In agreement with the results, it has been demonstrated that resistance exercise reduces heroin self-administration via the down-regulation of $\mathrm{D}_{1}$ versus $\mathrm{D}_{2}$ receptors in the nucleus accumbens core, but no significant differences were found between exercising and sedentary heroin-exposed rat groups in dopamine receptor mRNA expression at nucleus accumbens shell (Robison et al., 2018). Therefore, these differences in effects of exercise on drug abuse are probably related to the kind of drug abuse and site injection of dopamine receptors antagonists. Moreover, exercise can enhance dopamine and may be able to provide even more benefits in suppressing the reward from substance use (Volkow and Baler, 2014) .

\section{Conclusion}

In conclusion, the results of the present study demonstrated that treadmill running reduced morphine sensitization behavior and induced euphoria in rats. Previous studies revealed the effects of physical activity exert by the release of endogenous opioid and dopamine neurotransmitters in different parts of the 
brain. Moreover, we found that the microinjection of $\mathrm{D}_{1}$ and $\mathrm{D}_{2}$ antagonists into the $1 \mathrm{PAG}$ region decreased the reinforcement effects of morphine. Considering the association of aerobic exercise with dopamine antagonism, the role of the $\mathrm{D}_{2}$-receptor in the sensitization of morphine was more pronounced than that of the $\mathrm{D}_{1}$ receptor. It is likely that the running activity can protect against addiction via the release of dopamine by activating $\mathrm{D}_{2}$ dopamine receptors in the IPAG area.

\section{Acknowledgments}

The authors would like to express their gratitude to Isfahan University of Medical Sciences, Isfahan, Iran.

\section{Conflict of interest}

The authors declare no conflict of interests.

\section{References}

Ahmadi S, Radahmadi M, Alaei H, Ramshini E. Effect of aerobic exercise on morphine self administration and pain modulation in rats. Adv Biomed Res 2018; 7: 70-81. https://doi.org/10.4103/abr.abr_181_17

Alaei H, Esmaeili M, Nasimi A, PourshanazariA. Ascorbic acid decreases morphine self-administration and withdrawal symptoms in rats. Pathophysiology 2005; 12: 103-7. https://doi.org/10.1016/j.pathophys.2005.03.004

Avila-Luna A, Prieto-Leyva J, Galvez-Rosas A, AlfaroRodriguez A, Gonzalez-Pina R, Bueno-Nava A. D1 antagonists and $\mathrm{d} 2$ agonists have opposite effects on the metabolism of dopamine in the rat striatum. Neurochem Res 2015; 40: 1431-7. https://doi.org/10.1007/s11064015-1611-4

Boecker H, Sprenger T, Spilker ME, Henriksen G, Koppenhoefer M, Wagner KJ, et al. The runner's high: opioidergic mechanisms in the human brain. Cereb Cortex 2008; 18: 2523-31. https://doi.org/10.1093/cercor/ bhn013

Charmchi E, Zendehdel M, Haghparast A. The effect of forced swim stress on morphine sensitization: Involvement of d1/ d2-like dopamine receptors within the nucleus accumbens. Prog Neuropsychopharmacol Biol Psychiatry 2016; 70: 92-9. https://doi.org/10.1016/j.pnpbp.2016.05.006

Flores JA, El Banoua F, Galan-Rodriguez B, FernandezEspejo E. Opiate anti-nociception is attenuated following lesion of large dopamine neurons of the periaqueductal grey: Critical role for D1 (not D2) dopamine receptors. Pain 2004; 110: 205-14. https://doi.org/10.1016/j. pain.2004.03.036

Greenwood BN, Fleshner M. Exercise, stress resistance, and central serotonergic systems. Exerc Sport Sci Rev 2011; 39: 140-49. https://doi.org/10.1097/ JES.0b013e31821f7e45

Haghparast A, Omranifard A, Arezoomandan R, GhalandariShamami M, Taslimi Z, Vafaei AA, et al. Involvement of dopaminergic receptors of the rat nucleus accumbens in decreasing the conditioned place preference induced by lateral hypothalamus stimulation. Neurosci Lett 2013; 556: 10-4. https://doi.org/10.1016/j.neulet.2013.09.062

Hasue RH, Shammah-Lagnado SJ. Origin of the dopaminergic innervation of the central extended amygdala and accumbens shell: a combined retrograde tracing and immunohistochemical study in the rat. J Comp Neurol 2002; 454: 15-33. https://doi.org/10.1002/cne.10420

Hosseini M, Alaei HA, Havakhah S, Neemati Karimooy HA, Gholamnezhad Z. Effects of microinjection of angiotensin ii and captopril to vta on morphine self-administration in rats. Acta Biol Hung 2009a; 60: 241-52.

Hosseini M, Alaei HA, Naderi A, Sharifi MR, Zahed R. Treadmill exercise reduces self-administration of morphine in male rats. Pathophysiology 2009b; 16: 3-7. https://doi. org/10.1016/j.pathophys.2008.11.001

Hoveida R, Alaei H, Oryan S, Parivar K, Reisi P. Treadmill running improves spatial memory in an animal model of alzheimer's disease. Behav Brain Res 2011; 216: 270-4. https://doi.org/10.1016/j.bbr.2010.08.003

Hyman SE, Malenka RC, Nestler EJ. Neural mechanisms of addiction: the role of reward-related learning and memory. Annu Rev Neurosci 2006; 29: 565-98. https://oi. org/10.1146/annurev.neuro.29.051605.113009

Lane DA, Patel PA, Morgan MM. Evidence for an intrinsic mechanism of antinociceptive tolerance within the ventrolateral periaqueductal gray of rats. Neuroscience 2005; 135: 227-34. https://doi.org/10.1016/j. neuroscience.2005.06.014

Li C, Sugam JA, Lowery-Gionta EG, McElligott ZA, McCall $\mathrm{NM}$, Lopez AJ, et al. Mu opioid receptor modulation of dopamine neurons in the periaqueductal gray/dorsal raphe: a role in regulation of pain. Neuropsychopharmacology 2016; 41: 2122-32. https://doi.org/10.1038/npp.2016.12

Liu J, Chen L, Chen X, Hu K, Tu Y, Lin M, et al. Modulatory effects of different exercise modalities on the functional connectivity of the periaqueductal grey and ventral tegmental area in patients with knee osteoarthritis: A randomised multimodal magnetic resonance imaging study. 
Br J Anaesth 2019; 123: 506-18. https://doi.org/10.1016/j. bja.2019.06.017

Liu Y, Wu YW, Qian ZQ, Yan CF, Fan KM, Xu JH, et al. Effect of opioid receptors on acute stress-induced changes in recognition memory. Sheng Li Xue Bao 2016; 68: 75766.

Łupina M, Tarnowski M, Baranowska-Bosiacka I, Talarek S, Listos P, Kotlińska J, et al. SB-334867 (an orexin-1 receptor antagonist) effects on morphine-induced sensitization in mice-a view on receptor mechanisms. Mol Neurobiol 2018; 55: 8473-85. https://doi.org/10.1007/s12035-0180993-0

Lynch WJ, Peterson AB, Sanchez V, Abel J, Smith MA. Exercise as a novel treatment for drug addiction: A neurobiological and stage-dependent hypothesis. Neurosci Biobehav Rev 2013; 37: 1622-44. https://doi.org/10.1016/j. neubiorev.2013.06.011

McDougall SA, Reichel CM, Cyr MC, Karper PE, Nazarian A, Crawford CA. Importance of D 1 receptors for associative components of amphetamine-induced behavioral sensitization and conditioned activity: a study using D 1 receptor knockout mice. Psychopharmacology 2005; 183: 20-30. https://doi.org/10.1007/s00213-005-0146-9

Meyer PJ, Fossum EN, Ingram SL, Morgan MM. Analgesic tolerance to microinjection of the $\mu$-opioid agonist damgo into the ventrolateral periaqueductal gray. Neuropharmacology 2007; 52: 1580-5. https://doi. org/10.1016/j.neuropharm.2007.03.002

Meyer PJ, Morgan MM, Kozell LB, Ingram SL. Contribution of dopamine receptors to periaqueductal gray-mediated antinociception. Psychopharmacology 2009; 204: 531-40. https://doi.org/10.1007/s00213-009-1482-y

Moradi M, Fatahi Z, Haghparast A. Blockade of D1-like dopamine receptors within the ventral tegmental area and nucleus accumbens attenuates antinociceptive responses induced by chemical stimulation of the lateral hypothalamus. Neurosci Lett 2015; 599: 61-66. https://doi. org/10.1016/j.neulet.2015.05.047

Nestler EJ. Molecular basis of long-term plasticity underlying addiction. Nat Rev Neurosci 2001; 2: 119-28. https://doi. org/10.1038/35053570

Paxinos G, Watson C. The rat brain in stereotaxic coordinates. London: Elsevier Academic, 2006.

Reisi Z, Bani-Ardalan M, Zarepour L, Haghparast A. Involvement of D1/D2 dopamine receptors within the nucleus accumbens and ventral tegmental area in the development of sensitization to antinociceptive effect of morphine. Pharmacol Biochem Behav 2014; 118: 16-21. https://doi.org/10.1016/j.pbb.2013.12.023

Robison LS, Swenson S, Hamilton J, Thanos PK. Exercise reduces dopamine D1R and increases D2R in rats: implications for addiction. Med Sci Sports Exerc 2018; 50: 1596-602. https://doi.org/10.1249/ MSS.0000000000001627

Sadeghzadeh F, Babapour V, Haghparast A. Role of dopamine D1-like receptor within the nucleus accumbens in acute food deprivation-and drug priming-induced reinstatement of morphine seeking in rats. Behav Brain Res 2015; 287: 172-81. https://doi.org/10.1016/j.bbr.2015.03.055

Sahraei H, Poorheidari G, Foadaddini M, Khoshbaten A, Asgari A, Noroozzadeh A, et al. Effects of nitric oxide on morphine self-administration in rat. Pharmacol Biochem Behav 2004; 77: 111-6. https://doi.org/10.1016/j. pbb.2003.10.008

Schetz JA, Sibley DR. Dopaminergic neurotransmission. Handbook of contemporary neuropharmacology 2007. https://doi.org/10.1002/9780470101001.hen007

Silva MT, Heyman GM. Chronic morphine consumption decreases wheel running and wheel running-reinforced behavior in rats. Pharmacol Biochem Behav 2001; 69: 517. https://doi.org/10.1016/S0091-3057(01)00498-1

Smith MA, Fronk GE, Abel JM, Lacy RT, Bills SE, Lynch WJ. Resistance exercise decreases heroin selfadministration and alters gene expression in the nucleus accumbens of heroin-exposed rats. Psychopharmacology 2018; 235: 1245-55. https://doi.org/10.1007/s00213-0184840-9

Smith MA, Lynch WJ. Exercise as a potential treatment for drug abuse: evidence from preclinical studies. Front Psychiatry 2011; 2: 82. https://doi.org/10.3389/ fpsyt.2011.00082

Tobaldini G, Reis RA, Sardi NF, Lazzarim MK, Tomim $\mathrm{DH}$, Lima $\mathrm{M}$, et al. Dopaminergic mechanisms in periaqueductal gray-mediated antinociception. Behav Pharmacol 2018; 29: 225-33. https://doi.org/10.1097/ FBP.0000000000000346

Volkow ND, Baler RD. Addiction science: Uncovering neurobiological complexity. Neuropharmacology 2014; 76: 235-49. https://doi.org/10.1016/j. neuropharm.2013.05.007

Voulalas PJ, Ji Y, Jiang L, Asgar J, Ro JY, Masri R. Loss of dopamine D1 receptors and diminished D1/5 receptormediated ERK phosphorylation in the periaqueductal gray after spinal cord lesion. Neuroscience 2017; 343: 94-105. 
https://doi.org/10.1016/j.neuroscience.2016.11.040

Yoshida K, Nonaka T, Nakamura S, Araki M, Yamamoto T. Microinjection of 26RFa, an endogenous ligand for the glutamine RF-amide peptide receptor (QRFP receptor), into the rostral ventromedial medulla (RVM), locus coelureus (LC), and periaqueductal grey (PAG) produces an analgesic effect in rats. Peptides 2019; 115: 1-7. https:// doi.org/10.1016/j.peptides.2019.02.003 